\title{
Review
}

\section{Friendship among nations: History of a concept}

\author{
Evgeny Roshchin \\ Manchester University Press, 2017, 254, ISBN: 978-1-5261-1644-4
}

Contemporary Political Theory (2020) 19, S231-S234. https://doi.org/10.1057/s41296019-00323-1; published online 16 May 2019

As a leading friendship scholar, Evgeny Roshchin's latest work, Friendship Among Nations: History of a Concept has been long awaited. Roshchin takes a unique position in the current debates in friendship studies, his conceptual approach being in stark contrast to the more dominant structural, individual, and state-centred approaches. While offering one of the more theoretical approaches to the study of friendship in politics, Roshchin's work also succeeds in revealing the deeper meaning behind the praxis of friendship in politics.

Friendship Among Nations builds on Roshchin's previous works where he draws upon conceptual history to illustrate the development of the concept of friendship in international diplomacy, from the ancient era up to modern history, highlighting that modern conceptualisations are deeply indebted to both ancient and mediaeval ones. That means Roshchin's findings are highly relevant to both for our own theoretical understanding of friendship, and for what friendship practically means when it is invoked in the context of international treaties. In a field overwhelmingly concerned with the positive side of friendship, Roshchin's conceptual approach stands out both in its realistic outlook, and in what it has to teach us about the negative side of the utilitarian aspect of friendship.

Chapter 1 critically discusses the history of political thought since Aristotle's seminal demarcation between pleasure, utility, and virtue-friendship. Chapter 2 details the conceptual development of friendship agreements in the 16th and 17th century. Chapter 3 illustrates the development of a normative approach of friendship, and Chapter 4 analyses the slow disappearance of utility friendship in the 17th and 18th century. This all builds towards Chapter 5, which showcases the implications of ancient assumptions underlying modern understandings of friendship. These are brilliantly illustrated by Roshchin in his analysis of both bilateral friendship treaties and the friendship treaties signed between the native populations and colonialising powers.

Starting with Aristotle, friendship scholars have differentiated between one higher form of friendship, commonly denoted as virtue-friendship, and one or more

(c) 2019 Springer Nature Limited. 1470-8914 Contemporary Political Theory Vol. 19, S4, S231-S234 
lower forms, i.e. Aristotle's pleasure and utility friendship. With the notable exception of Francis Bacon's work (1627a, b), and Cicero's earlier focus on the practical aspects of friendship (1923), friendship scholars have remained loyal followers of Aristotle. By drawing our attention to friendship's utility, both from a theoretical (Chapter 1) and practical perspective, Roshchin effectively recalibrates the debate, emphasising 'not so much the absolute value of concord and integrity, but the legitimacy and practical aspects of friendship of utility, that is, political friendship' (p. 32). The value of this theoretical contribution - a return to the praxis of friendship - cannot be overemphasised, especially in a field which remains dominated by works that draw upon Aristotle's virtue-friendship.

In Chapter 5, 'The unknown friendship of the modern international order', Roshchin illustrates both how powerful friendship agreements can be and how ancient assumptions underlying modern conceptualisations have important implications for our political understanding of friendship. This chapter is especially relevant for IR scholars because 'friendship treaties concluded by the parties in that period dealt with the issues of sovereignty and commerce' (p. 218). Indeed, 'the recovery of the lost concept can move IR debates beyond the opposition of normative and sceptical understandings of friendship by showing that there can be more than one concept of friendship' (p. 219). Chapter 5 first discusses the advantages and drawbacks of bilateral friendship treaties (pp. 175-186), demonstrating the essential utility of friendship in modern history. It is in the second part of the chapter that Roshchin's contribution to our understanding of friendship truly shines. There Roshchin analyses the role friendship treaties played in colonialisation, showing how they were used in the subjugation of native Americans and in British imperial politics in India (pp. 186-218), thereby convincingly demonstrating the negative repercussions these politics of friendship had historically, and how these conceptualisations still impact our contemporary understandings.

Highlighting the role friendship treaties had in imperialism and in the foundation of the United States is novel and refreshing, especially because the language of friendship masked a malignant intent, notoriously when 'some of the most brutal massacres of native Americans were ordered under the pretext that they had disrespected the "friendship and kindness" which has continually been bestowed upon them' (p. 190). The strength of Roshchin's approach emerges when he shows how the underlying ancient meanings of friendship treaties - subjugation in return for protection - survived the classical era. Indeed the friendship treaties ancient Rome entered into appear more akin to modern protection rackets, and 'the US in fact resurrected the old practice of colonial agreements with so-called tributary tribes of granting friendship together with protection' (p. 205).

Roshchin's work is an important wake-up call for political theorists. The appeal of Friendship Among Nations goes far beyond friendship scholars, especially since his conceptual approach can be readily applied to other case studies, to reveal the ramifications of ancient assumptions underlying our contemporary understanding 
of politics. New students of friendship will be drawn to Roshchin's excellent introductory chapters on the subject, while established friendship scholars will be challenged to confront their overreliance on Aristotle's virtue-friendship. Meanwhile IR scholars, a field that has especially seen an increase in friendship scholarship in the last decades, will find an in-depth understanding of both the negative and the positive role of friendship between states, especially benefitting from the deeper understanding Roshchin brings to both the economic and political power of friendship treaties. Chapter 5 is the book's zenith. One of the major drawbacks of the conceptual approach is that both parts of Chapter 5 could stand as impressive tomes on their own, and, whether by Roshchin or his followers, these parts certainly deserve to be developed, and would make imminently valuable contributions.

Finally, a minor criticism can be levied against Roshchin's own criticism of the dominance of Aristotle's virtue-friendship in the academic debate. While it certainly makes sense to start with discussing Aristotle, critically and in-depth, more could have been made, for example, of recent contributions on Plato's vision on friendship, especially Plato's honour-based conception (Sheffield, 2011, pp. 258-259; Vlastos, 2000). The latter seems a missing link to Aristotle's utility-friendship, and therefore might very well offer another fruitful approach for stressing both the importance of conceptualising utility-friendship and moving away from an overreliance on Aristotle.

Friendship Among Nations shines in its theoretical contribution: the appeal to address our overreliance on Aristotle's virtue-friendship and an exemplary analysis of the overlooked utilitarian aspect of friendship. The practical implications most notably come to the fore in Chapter 5, detailing how friendship treaties were employed by imperial powers to subjugate native populations. Roshchin's theoretical and practical conclusions make Friendship Among Nations important for political theorists and friendship scholars alike. Yet it is not hard to imagine the wide popular appeal, and impact, Chapter 5 could have as a sole work. With this work, Roshchin challenges us to consider the politics of friendship in its entirety, and to analyse, whether they be negative or positive, all of its aspects.

\section{References}

Bacon, F. (1627a) Of Followers and Friends. Essays of Francis Bacon. http://www.bartleby.com/3/1/48. html.

Bacon, F. (1627b) Of Friendship. Essays of Francis Bacon. http://www.bartleby.com/3/1/27.html.

Cicero, M.T. (1923) On Old Age. On Friendship. On Divination. Translated by William Armistead Falconer. Nachdr. Loeb Classical Library 154. Cambridge, MA: Harvard University Press.

Sheffield, F.C.C. (2011) VIII - Beyond Eros: friendship in the phaedrus. Proceedings of the Aristotelian Society 111(2): 251-273. https://doi.org/10.1111/j.1467-9264.2011.00308.x.

(c) 2019 Springer Nature Limited. 1470-8914 Contemporary Political Theory Vol. 19, S4, S231-S234 S233 
Vlastos, G. (2000) The Individual as an Object of Love in Plato. In: G. Fine (ed.) Plato 2. Ethics, Politics, Religion, and the Soul. Oxford Readings in Philosophy. Oxford: Oxford University Press, pp. 37-164.

Publisher's Note Springer Nature remains neutral with regard to jurisdictional claims in published maps and institutional affiliations.

Yuri van Hoef

Utrecht University, 3512 JE Utrecht, The Netherlands y.vanhoef@uu.nl 